Univerzitet u Beogradu
Poljoprivredni fakultet
Institut za poljoprivrednu tehniku
Naučni časopis
POLJOPRIVREDNA TEHNIKA
Godina XLIV
Broj 4, 2019.
Strane: $27-38$

\title{
EVALUATION OF UNIFORMITY AND WATER CONVEYANCE EFFICIENCY OF SPRAY TUBE IRRIGATION SYSTEM
}

\author{
Ransford Opoku Darko*1,2, Shouqi Yuan ${ }^{1}$, Junping Liu ${ }^{1}$, Haofang Yan ${ }^{1}$, \\ Abindau Ibrahim ${ }^{2}$ \\ ${ }^{1}$ Research Centre of Fluid Machinery Engineering and Technology, \\ Jiangsu University, Zhenjiang 212013, China \\ ${ }^{2}$ Department of Agricultural Engineering, University of Cape Coast, \\ Central Region, Cape Coast, PMB Ghana
}

\begin{abstract}
Irrigation water is one of the limited resources and need to be managed efficiently in order to meet crop water requirement. Thus, water resources have to be utilized in such a manner as to protect and conserve the available water reserves in the most efficient way as possible to prevent unnecessary losses and water wastage. In view of this, the research evaluates the uniformity and water conveyance efficiency of spray tube irrigation system using sixty catch cans at different spacing intervals of $0.5 \mathrm{~m} \times 0.5$ $\mathrm{m}, 1 \mathrm{~m} \times 1 \mathrm{~m}, 1.5 \mathrm{~m} \times 1.5 \mathrm{~m}$ and finally with $2 \mathrm{~m} \times 2 \mathrm{~m}$. The results shows that value of Christiansen's coefficient of uniformity (CU) ranges from $87 \%$ to $92 \%$, distribution uniformity (DU) ranges from $79 \%$ to $88 \%$ and scheduling coefficient $(\mathrm{Sc}$ ) ranges from 1.13 to 1.27 . Efficient performance and delivery of the spray tube irrigation system is envisaged to help cut down operational cost, water losses and to increase crop yield.
\end{abstract}

Keywords: Spray tube irrigation, Uniformity, Water, Efficiency

\section{INTRODUCTION}

Historically, early irrigation works were typically implemented to ensure human physical survival. In the absence of large populations, industries and recreation, there was not much competition for water except among neighboring irrigators sharing the same source of water.

*Corresponding Author. E-mail: chiefrodark@yahoo.com 
As human activities increases, engineers also build upon improving irrigation system, the chief concern was production of crop according to Clemmens et al. [1].

According to Ismail and Ozawa [2] in their research stated that in the arid and semiarid as well as tropical regions, water shortage is a normal phenomenon and seriously limits agricultural potential. Water is one of the limited resources and need to be managed efficiently in order to meet the crop water requirement.

Thus, water resources have to be utilized in such a manner as to protect and conserve the available water reserves. In irrigated agriculture, this will be made possible through the effective management of water consumption [3].

Sprinkler irrigation is a method of applying irrigation water which is similar to natural rainfall. Water is distributed throughout system pipes usually by pumping. It is then sprayed into the air through spray tube so that it breaks up into small water drops which fall to the ground. This has brought about the use of spray irrigation system which evenly distributes the water in a form of spray with the use of spray tubes. In the spray tubes irrigation method, water is sprayed into the air and allowed to fall on the ground surface in a form resembling rainfall. The spray is developed by the flow of water under pressure through small orifices or small holes.

According to Yuan et al. [4] sprinkler irrigation systems with poor uniformity results in reduced yields due to water stress as well as water logging which contribute to an increase in the cost of irrigation and other related issues. Modern spray tube irrigation technologies usually convey water through pipes hence resulting in less water wastage. Spray tube irrigation systems seem to have large potential for improving water use efficiency of crops. Spray tube irrigation produces positive yields in relation to water savings and increases crop productivity, but one of the concerns is the uniform distribution, which is the spatial distribution irrigation applied in a regular way throughout the area in which the water is needed. Irrigation uniformity is an important performance characteristic of the spray tube irrigation system and is necessary paramount when evaluating the performance of the system. Spray tubes properly spaced will respond to a relatively uniform application of water over the irrigated area. According to Tim and Zoldoske [5], uniformity is how evenly a sprinkler delivers water over the ground. The distribution uniformity of a system has an effect on the system's application efficiency and on the crop yield $[6,7,8,9]$. Irrigation systems with poor distribution uniformity experience reduced yields due to water stress and/or water logging [1]. Poor distribution uniformity also increased financial and environmental costs. Nutrients can be leached out of the soil due to excess water being applied to overcome poor irrigation uniformity; this will increase fertilizer costs and pumping costs, and may have environmental impacts if the excess runoff and deep percolation are contaminated with nutrients [8].

The distribution uniformity of an irrigation system depends both on the system characteristics and on managerial decisions [10]. The issue of uniformity and efficiency of spray tube irrigation system has still not been properly addressed mostly with spray tube irrigation system. This duels to the fact that uniformity and efficiency assessment is very important when it comes to crop water management and performance. It is therefore of a paramount interest to evaluate spray tube irrigation systems based on their ability to establish uniformity in water application to identify run times that minimize dry areas. 
It is in the light of this that this research was carried out to generally determine the uniformity and water conveyance efficiency of the spray tube irrigation system using different spacing intervals of catch cans.

\section{METHODOLOGY}

Field experiments were conducted during the dry seasons from December to February of 2018-2019. at a farmers Farm in the Central Region of Ghana. The experimental area has a semi-arid climate with wet season and hot dry season. Table 1 below shows the soil physical and chemical properties of the experimental site.

Table 1: Soil Physical Properties

\begin{tabular}{ccccccc}
\hline $\begin{array}{c}\text { Bulk } \\
\text { density } \\
\left(\mathrm{g} / \mathrm{cm}^{3}\right)\end{array}$ & $\begin{array}{c}\text { Particle } \\
\text { density } \\
\left(\mathrm{g} / \mathrm{cm}^{3}\right)\end{array}$ & $\begin{array}{c}\text { Pores } \\
\%\end{array}$ & $P^{H}$ & $\begin{array}{c}\text { Sand } \\
\%\end{array}$ & $\begin{array}{c}\text { Silt } \\
\%\end{array}$ & $\begin{array}{c}\text { Clay } \\
\%\end{array}$ \\
\hline 1.34 & 2.48 & 48 & 5.3 & 75 & 20 & 5 \\
\hline
\end{tabular}

The land was first cleared with the use of cutlass to give an open space and to enable an easy working field. The grasses and stumps were carried off the farm leaving only soft weeds on the surface of the farm as a mulch to conserve moisture and enable easy installation of the irrigation system. The farm was left unploughed (minimum or zero tillage practices) and leveled.

\section{Installation of the System}

The spray tube irrigation system (Figure 1) is made up of the following features that come together to form the system; the pumping machine, two inches PVC pipes (Main pipes), Irrigation spray tubes, The valves (main valve and the spray tube valves), PVC suction intake pipe and the end pegs.

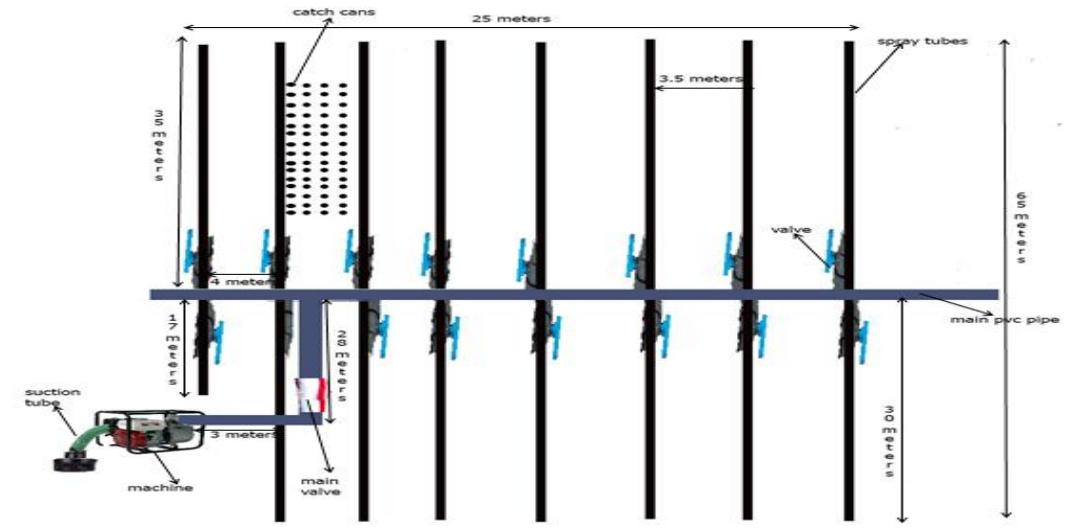

Figure 1: Experimental field layout of Spray tube irrigation system 
The source of water was first cleared open to enable the easy implantation of the pump suction intake hose into the water source. The dimensions of the land area were taken to determine the total land size of the area which was 1625 square meters. The suction intake hose with the Strainer fitted was connected to water pump machine and the machine was then connected to the outtake (discharge port) which was step down from the three inches to two inches PVC pipes which is the main pipe. The pump machine applied suction pressure which pulls water from the sources through the suction intake hose to the machine and through the outtake. The pump machine was set to deliver a constant volume of 500 litres per minute and WCE was calculated using the volume of water delivered within one hour at each spacing interval. The outtake was made up of two inches PVC pipe which were glued together to form a long pipe which is the main pipe.

From the out take (discharge port) at a distance of three meters along the main line was a main valve which controls the flow back of water out of the system. The main pipe was curved left at an angle of $90^{\circ}$ along the length of farm. At a distance of twenty eight meters, the pipe was also curved rightwards at an angle of $90^{\circ}$ across the length of the farm. The valves holes were bored through the main PVC pipe at an interval of 3.5 meters. The valves were fitted to the main pipe with the help of valves rings at both holes of pipe. These valves regulate the movement of water into the irrigation spray tubes. The spray tubes were then connected to the valves with the perforated hole facing upwards. The spray tubes were laid along the farm and pegged at ends of the farm which help them to lie straight along the measured dimension. The pegging was done at an interval of 3.5 meters as the spacing on the main pipe. The ends of the main pipe were closed to create a pressure build up within the spray tube for effective spraying.

\section{Uniformity Test Experiment}

The uniformity experiments were carried out with catch cans (Figure 2) of the same size and diameter. A total of sixty (60) catch cans were used. A portion was selected in between the spray tubes where the experiment was carried out. The catch cans were first distributed evenly in the farm using a spacing of half $(0.5)$ meter by half $(0.5)$ meter interval between the catch cans and it was represented by $\left(\mathrm{S}_{1}\right)$. The catch cans were placed with their openings facing upwards to collect the water. The machine was powered and the system was set to run for an hour with a constant pressure $30 \mathrm{psi}$ and discharge rate (500 liters per minute) and after then the volume of water collected in each catch can was measured and recorded. With the same intervals the experiment was repeated three times represented as $\mathrm{R} 1, \mathrm{R} 2$, and $\mathrm{R} 3$.

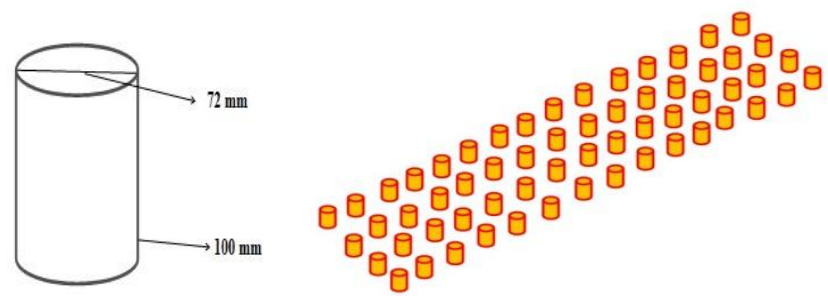

Figure 2: Catch cans layout 
The experiment was carried out with the same number of catch cans using the same pressure from the pump and discharge rate but with an interval of one (1) meter by one (1) meter apart represented as $\left(\mathrm{S}_{2}\right)$; one and half (1.5) meters by one and half (1.5) meters represented as $\left(S_{3}\right)$ and with a spacing interval of two (2) meters by two (2) meters of the catch cans represented as $\left(\mathrm{S}_{4}\right)$. Each spacing was replicated three times denoted as R1, R2 and R3 and the volume water collected in each catch can was measured and recorded.

Christiansen's coefficient of uniformity (CU) was expressed as a measure of the absolute difference from the mean divided by the mean expressed as a percentage below:

$$
\mathrm{CU}=100\left[1-\frac{\sum_{\mathrm{i}=1}^{\mathrm{n}}\left|\mathrm{x}_{\mathrm{i}}-\overline{\mathrm{X}}\right|}{\mathrm{n} \overline{\mathrm{X}}}\right]
$$

Where is :

$X_{i}$ - water depth collected from the $i^{\text {th }}$ catch can, $\mathrm{mm} / \mathrm{h}$;

$\bar{X}$ - mean water depth collected in all catch cans within the area, $\mathrm{mm} / \mathrm{h}$;

$\mathrm{n}$ - the total number of catch cans in the area under consideration.

The distribution uniformity (DU), proposed by Merriam and Keller (1978) was also computed by dividing the mean low quarter caught in the cans by the average depth caught in all the cans expressed as a percentage. Their equation is as follows:

$$
\mathrm{DU}=100\left[\frac{\mathrm{Dlq}}{\mu}\right]
$$

Where is : DU - distribution uniformity, \%

Dlq - mean of the lowest one-quarter of the measured depths, mm.

The scheduling coefficient $(\mathrm{Sc})$ also represents the ratio of area receiving the least amount of water to the average amount of water applied through the irrigation area. This value of measurement is considered very important which enables us to find the critical area in the water application pattern [7].

Mathematically, $\mathrm{Sc}$ is defined as:

$$
\mathrm{Sc}=100\left[\frac{1}{\mathrm{DU}}\right]
$$

The entry area of the Catch can is the upwards opened area of the catch can which enables it to trap water that is sprayed up by the spray tube. The wider the entry area, the higher the volume of water that can be trapped and the smaller the entry area, the smaller the volume of water that would be trap by the catch can. The catch cans were cylindrical in shape with an inside diameter of 72 millimeters and a height of 100 millimeters.

The entry area is calculated with the formula;

Area $=\pi r^{2}$ 


\section{Water Conveyance Efficiency (WCE)}

Water conveyance efficiency is the ratio of volume of irrigation water delivered by the distribution system to the water introduced into the system. This takes into account the conveyance or transit losses and is determined from the following expression:

$$
\mathrm{WCE}=\frac{\mathrm{Wf}}{\mathrm{Wi}}
$$

Where is:

WCE - water conveyance efficiency

Wf - volume of irrigation water delivered by the distribution system

Wi - water introduced into the system

$\mathrm{WCE}=\frac{\text { volume of irrigation water delivered by a distribution system }}{\text { water introduced into the system. }} \times 100$

\section{Statistical Analysis Results}

Data collected was subjected to the analysis of variance (ANOVA) procedure using GenStat Software Statistical tool to investigate whether there were statistical differences in the parameters studied.

\section{RESULTS AND DISCUSSION}

\section{Water Distribution Pattern}

Water collected in catch cans depicts the water distribution pattern, volume of water (ml) captured in each catch can was measured using a volumetric flask, hence, the pattern of distribution as observed in Figure 3. Water collected was generally higher at spacing interval $s_{1}$ and it generally decrease to lower values at $s_{4}$.

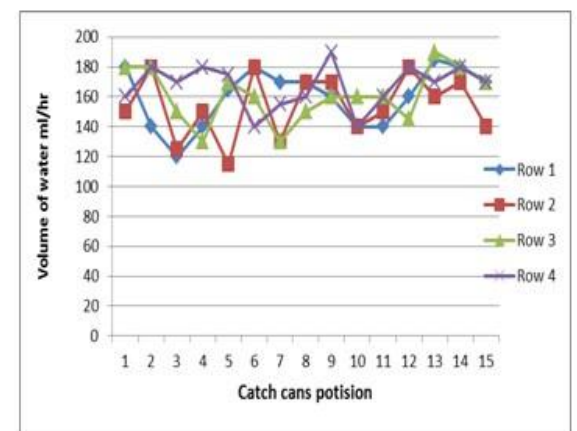

Figure 3a: Water distribution pattern in catch cans at $S_{I}$

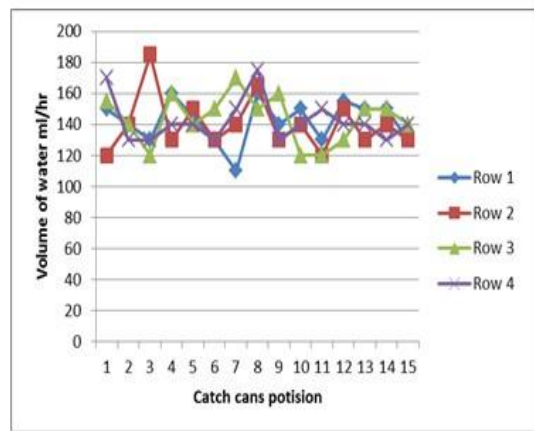

Figure 3b: Water distribution pattern in catch cans at $\mathrm{S}_{2}$ 


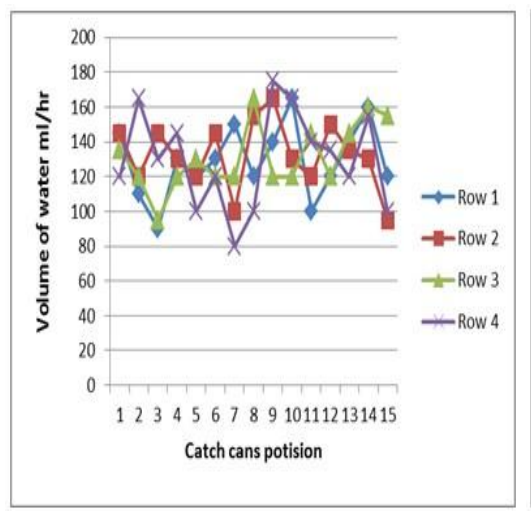

Figure 3c: Water distribution pattern in catch cans at $S_{3}$

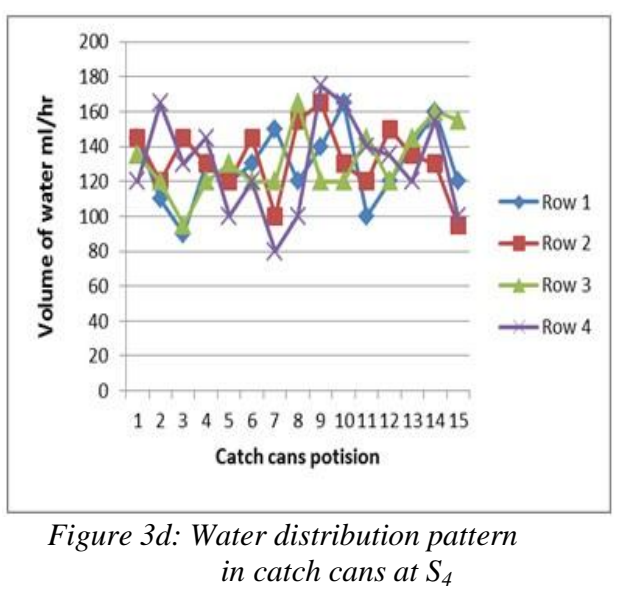

Figure $3 a, 3 b, 3 c$ and $3 d$ shows the water distribution pattern where $3 a$ shows the water distribution pattern for $S_{1}, 3 b$ represents the water distribution pattern for $S_{2}, 3 c$ represent the water distribution pattern for $S_{3}$ and $3 d$ represent water distribution pattern for $\mathrm{S}_{4}$. The mean water distribution in catch can observed in Figure $3 \mathrm{a}, 3 \mathrm{~b}, 3 \mathrm{c}$ and $3 \mathrm{~d}$ were $160.58 \mathrm{ml}, 14 \mathrm{ml}, 130.75 \mathrm{ml}$ and $125 \mathrm{ml}$ respectively. As observed in the water distribution pattern curves, generally, catch cans volumes differences in $3 \mathrm{a}$ and $3 \mathrm{~b}$ are very close with higher mean values implying that much water was collected by catch cans placed in these replications. But in $3 \mathrm{c}$ and $3 \mathrm{~d}$, the mean value decreased due to the wider spacing interval used thereby spreading out the line graph. Spacing interval $S_{1}$ relatively collected more water than that of $\mathrm{S}_{2}, \mathrm{~S}_{3}$ and $\mathrm{S}_{4}$, because majority of its catch can volumes peaked at $180 \mathrm{ml}$ whereas only one catch can had its peak at $180 \mathrm{ml}$ in $\mathrm{S}_{2}$. At $\mathrm{S}_{3}$ and $\mathrm{S}_{4}$ catch can volumes are less than $180 \mathrm{ml}$.

These variabilities in pattern of water distribution could be attributed to the differences in spacing interval used for the spray tube as well as wind distortion which usually brings about a reduction in the wetted area [12.13].

\section{Coefficient of Uniformity (CU)}

Several researches have been done on uniformity and efficiencies and they vary from irrigation system to irrigation system. Coefficient of uniformity was calculated using Christiansen formula [14]. Analysed data in Table 2 indicates that there is no significant difference within the treatment $s_{1}$ coefficient of uniformity (CU) but there exist significant differences between the treatments $s_{1}$ to $s_{4}$ with the exception of replication three which has no significant differences between the treatments from $s_{1}$ to $s_{4}$ and this may be as a result of variations in pressure distribution within the spray tubes, wind speed and direction and spray tube spacing. 
Table 2: Coefficient of Uniformity

\begin{tabular}{cccc}
\hline \multirow{2}{*}{ Spacing } & \multicolumn{3}{c}{ Coefficient of Uniformity $(\boldsymbol{C U})$} \\
\cline { 2 - 4 } & $\boldsymbol{R} \mathbf{( \% )}$ & $\begin{array}{c}\boldsymbol{R} \mathbf{2} \\
(\boldsymbol{\%})\end{array}$ & $\begin{array}{c}\boldsymbol{R} 3 \\
(\boldsymbol{\%})\end{array}$ \\
\hline$S_{1}$ & $91.74 a$ & $91 a$ & $90 a$ \\
$S_{2}$ & $90.49 a b$ & $91 a$ & $89 a$ \\
$S_{3}$ & $86.6 a b$ & $90 a b$ & $87 a$ \\
$S_{4}$ & $86.13 b$ & $87 b$ & $87 a$ \\
\hline
\end{tabular}

Distinct letters in the column indicate significant differences according to ANOVA test ( $p \leq 0.05)$.

All the treatments with their replications obtained a coefficient of uniformity ranging from $80 \%$ to $95 \%$ which is excellent, hence the system supplies water uniformly. Significant differences that exist between treatments may be due to wind speed and direction as well as the layout of spray tube.

With respect to the values obtained above, it is within the satisfactory range. According to Michael [13], a satisfactory uniformity coefficient should be $85 \%$ or more. Dwomoh et al. [15] also recommended uniformity values under low and moderate wind speed conditions as ranging between $80 \%$ and $90 \%$.

\section{Distribution Uniformity (DU)}

Distribution Uniformity (DU) results in Table 3 also indicates that there is no significant difference within replications of treatment $S_{1}$.

Table 3: Distribution Uniformity

\begin{tabular}{|c|c|c|c|}
\hline \multirow{2}{*}{ Spacing } & \multicolumn{3}{|c|}{ Distribution Uniformity $(\mathrm{DU})$} \\
\hline & $\begin{array}{l}R 1 \\
(\%)\end{array}$ & $\begin{array}{l}R 2 \\
(\%)\end{array}$ & $\begin{array}{l}R 3 \\
\text { (\%) }\end{array}$ \\
\hline$S_{1}$ & $88 a$ & $86 a$ & $86 a$ \\
\hline$S_{2}$ & $84 b$ & $85 a$ & $81 b$ \\
\hline $\mathrm{S}_{3}$ & $80 d$ & $84 a$ & $79 b$ \\
\hline $\mathrm{S}_{4}$ & $81 c$ & $81 a$ & $79 b$ \\
\hline
\end{tabular}


There is no significant difference between the treatments $s_{1}$ to $s_{4}$ for replication two but there exist a significant difference between the treatments $s_{1}$ to $s_{4}$ for replication one and replication three. In Table 3, majority of distribution uniformity (DU) falls within the recommended range; $85 \%$ and above, and very good ranges ( $80 \%$ and above) with few of them been above $70 \%$ which is also good. According to the literature, Solomon (1988), Keller and Bliensner [16], Jorge and Pereira [17] as well as Rain Baird [18] found that the uniformity of distribution ranged from 75 to $85 \%$ which is widely accepted. Significant differences in DU were due to the effects of wind and the position of the spray tube holes.

\section{Scheduling Coefficient (Sc)}

In Table 5, the analyzed data for scheduling coefficient (Sc) shows that there is no significant difference that existed between the treatment $\left(s_{1}\right.$ to $\left.s_{4}\right)$ in replication one but significant differences existed between the treatments for replication two and three.

Table 5: Scheduling Coefficient

\begin{tabular}{|c|c|c|c|}
\hline \multirow{2}{*}{ Spacing } & \multicolumn{3}{|c|}{ Scheduling Coefficient (Sc) } \\
\hline & $\begin{array}{l}R 1 \\
(\%)\end{array}$ & $\begin{array}{l}R 2 \\
(\%)\end{array}$ & $\begin{array}{l}R 3 \\
(\%)\end{array}$ \\
\hline$S_{1}$ & $1.13 a$ & $1.16 c$ & $1.16 c$ \\
\hline$S_{2}$ & $1.20 a$ & $1.18 b c$ & $1.23 b$ \\
\hline$S_{3}$ & $1.25 a$ & $1.19 b$ & $1.27 a$ \\
\hline $\mathrm{S}_{4}$ & $1.24 a$ & $1.23 a$ & $1.27 a$ \\
\hline
\end{tabular}

The scheduling coefficient of treatment $s_{4}$ shows no significant differences between the replications. The values of scheduling coefficient depend on the values of distribution uniformity. Scheduling coefficient value of less than 1.3 is considered as satisfactory according to Yuan et al. [4] who conducted their research and concluded a scheduling coefficient $(\mathrm{Sc})$ values which ranged from 1.13 to 1.42 for different pressure and height conditions. The values obtained above for all set of replication falls within the range recommended cited by other authors. 


\section{Water Conveyance Efficiency (WCE)}

Table 6 below shows the volume of water delivered to the farm at various treatments and their replications. Volumes of water delivered to the field by the irrigation system were measured to be different between parameters observed.

In Table 6 , the water conveyance efficiency at $s_{1}$ shows no significant differences within the replications, at $s_{2}$ there is no significant difference within the replications.

Table 6: Water Conveyance Efficiency

\begin{tabular}{cccc}
\hline & \multicolumn{3}{c}{ Water Conveyance Efficiency } \\
\cline { 2 - 4 } Spacing & $\boldsymbol{R} \mathbf{1}$ & $\begin{array}{c}\boldsymbol{R} \mathbf{2} \\
(\boldsymbol{\%})\end{array}$ & $\begin{array}{l}\boldsymbol{R 3} \\
(\boldsymbol{\%})\end{array}$ \\
\hline$S_{1}$ & $87 \boldsymbol{b}$ & $88 \boldsymbol{b}$ & $87 \boldsymbol{b}$ \\
$S_{2}$ & $97 \boldsymbol{c}$ & $98 \boldsymbol{c}$ & $95 \boldsymbol{c}$ \\
$S_{3}$ & $80 \boldsymbol{a} \boldsymbol{b}$ & $80 \boldsymbol{a}$ & $84 \boldsymbol{b}$ \\
$S_{4}$ & $77 \boldsymbol{a}$ & $83 \boldsymbol{a}$ & $79 \boldsymbol{a}$ \\
\hline Distinct letters in the column indicate significant differences according to ANOVA test $(p \leq 0.05)$.
\end{tabular}

But in $s_{3}$, there exist significant differences within the replications and in $s_{4}$, there is no significant differences within the replications. The table also indicates that, there exist significant differences between treatments $\left(s_{1}\right.$ to $\left.s_{4}\right)$. Water conveyance efficiency of a system take into consideration the amount of water the system can deliver to farm considering all loses that will occur along the transportation channel. Based on the values in Table 6, there exist some variations that are as a result of leakages in the pipe and spray tubes valves [19]. Considering all the efficiencies, the system is good, hence loses are minimal.

\section{CONCLUSION}

Uniformity assessment helps the farmer to identify the cropping method to use to maximize crop yield since this help to choose the crop density which is most appropriate and suitable for the available soil water. Coefficient of Uniformity (CU) values ranged from $87 \%$ to $92 \%$, Distribution Uniformity (DU) values ranged from $79 \%$ to $88 \%$ and Scheduling Coefficient $(\mathrm{Sc})$ values ranged from 1.13 to 1.27 obtained for the different spacing used is within the recommended range. Hence the spray tube irrigation system distributed water uniformly. Also, the Water Conveyance Efficiency (WCE) values obtained ranged from $77 \%$ to $98 \%$ thereby indicating efficient water delivery by the system.

The spacing interval $s_{1}(0.5$ meters by 0.5 meters) performed more satisfactory than the rest of the spacing intervals. Efficient performance and delivery of the spray tube irrigation is envisaged to help cut down operational cost, water losses and to increase crop yield. 


\section{Acknowledgement}

The National key research and development program No.2016YFC0400202, the key teacher training project of Jiangsu University and the Priority Academic Program Devel opment of Jiangsu Higher Education Institutions (PAPD and Department of Agricultural Engineering), School of Agriculture, University of Cape Coast, Ghana.

\section{REFERENCES}

[1] Clemmens, A.J. and Solomon, K.H. (1997). Estimation of global irrigation distribution uniformity. J. Irrigation Drainage Engineering, 123 (6) 454-461.

[2] Ismail S.M., Ozawa K. (2009). Effect of irrigation interval on growth characteristics, plant Water stress tolerance and water use efficiency for Chile pepper - Thirteenth International Water, Available at: pdfs.semanticscholar .org[ Accessed 05/11/2018]

[3] Darko, R. O., Yuan, S., Hong, L., Lui, J. and Yan, H. (2016) Irrigation, a productive tool for food security- a review. Acta Agriculturae Scandinavica, Section B- Soil \& Plant Science, 66(3): 191-206.

[4] Yuan S Q, Darko RO, Zhu X Y, Liu J P, Tian K. Optimization of movable irrigation system and performance assessment of distribution uniformity under varying conditions. Int. J Agric \& Biol Eng, 2017; 10(1):72-79.

[5] Tim, P.W. and Zoldoske, D.F. (1997). Evaluating Sprinkler irrigation Uniformity, CATI Publication \#970703, Available at: arborturfsolutions.com. [Accessed 15/12/2018]

[6] Letey, J. Vaux, H.J. and Feinerman, E. (1984). Optimum crop water applications as affected by uniformity of water infiltration. Agron. J. 76 435-441.

[7] Solomon, K. (1988). Irrigation systems and water application efficiencies. California State University, Fresno, California. 93740-0018.

[8] Solomon, K.H. (1990). Sprinkler irrigation uniformity. Centre for Irrigation Technology, California State University, Fresno, USA.

[9] Letey, J. (1985) Irrigation uniformity as related to optimum crop production- Additional research is needed. Irrigation Science. 6 253-263.

[10] Pereira, L.S. (1999). Higher performance through combined improvements in irrigation methods and scheduling: a discussion. Agricultural WaterManagement. 40 (2) 153-169.

[11] Seginer, I., Nir, D., and Bernuth. R. D. von, (1991). Simulation of wind-distorted sprinkler patterns. J. Irrig. Drain. Eng., ASCE 117(2): 285-306.

[12] Carrion, P., Tarjuelo, J. M., and Montero, J. (2001). SIRIAS: a simulation model for sprinkler irrigation: I Description of the model. Irrig. Sci. 20(2): 73-84.

[13] Michael, A. M. (1978). Irrigation theory and practice. Vikas Publishing House, PVT. Ltd. New Delhi, India.

[14] Christiansen J.E. (1942). Irrigation by Sprinkling. California Agricultural Experiment Station, Bull. 670, University of California, Berkley, USA.

[15] Dwomoh, F. A., Yuan, S., Li, H. (2013). Field performance characteristics of fluidic sprinkler. Applied Engineering in Agriculture. 29(4): 529-536.

[16] Keller, J. and Bliesner, R. D. (1990). Sprinkler and trickle irrigation. An Avi Book Van Nostrand Reinhold Pun, New York. 651.

[17] Jorge, J. and Pereira, L.S. (2002). Simulation and Evaluation of Set Sprinkler System with AVASPER Scientific paper published at www.google.com. Jorge Resu-N21.Pdf

[18] Rain Bird Corporation (2008). Distribution uniformity for sprinkler irrigation. USA. Available at: https://www.rainbird.com/documents/ag/L383 Distribution Uniformity_en.pdf. [ Accessed 17/12/2018] 
[19] Merriam, J. L. and Keller, J. (1978). Farm irrigation system evaluation: a guide for management. CEE Department, Utah State University, Logan, USA.

\title{
ISPITIVANJE UJEDNAČENOSTI I EFIKASNOST DISTRIBUCIJE VODE KOD SISTEMA ZA NAVODNJAVANJE SA RASPRSKIVAČIMA
}

\author{
Ransford Opoku Darko ${ }^{* 1,2}$, Shouqi Yuan ${ }^{1}$, Junping Liu ${ }^{1}$, Haofang Yan ${ }^{1}$, \\ Abindau Ibrahim ${ }^{2}$ \\ ${ }^{1}$ Research Centre of Fluid Machinery Engineering and Technology, \\ Jiangsu University, Zhenjiang 212013, China \\ ${ }^{2}$ Department of Agricultural Engineering, University of Cape Coast, \\ Central Region, Cape Coast, PMB Ghana
}

Sažetak. Voda za navodnjavanje je jedan od ograničenih resursa i sa njim se mora efikasno upravljati, da bi se zadovoljile potrebe useva za vodom. Zato se vodeni resursi moraju koristiti tako da se zaštite i sačuvaju raspoložive količine vode na najefikasniji način, i tako eliminišu nepotrebni gubici i rasipanje vode.

U ovom istraživanju se procenjuje ujednačenost $\mathrm{i}$ efikasnost distribucije vode sistemom za navodnjavanje sa rasprskivačima pomoću šezdeset uložaka u različitim intervalima rastojanja od $0,5 \mathrm{~m}$ x $0,5 \mathrm{~m} ; 1 \mathrm{~m}$ x $1 \mathrm{~m} ; 1,5 \mathrm{~m}$ x $1,5 \mathrm{~m}$ i konačno sa rastojanjem od $2 \mathrm{~m} \times 2 \mathrm{~m}$.

Rezultati ispitivanja rasprskivača pokazuju da se vrednost Christiansen koeficijenta uniformnosti raspodele vode (CU) kreće od $87 \%$ do $92 \%$, uniformnost distribucije (DU) u rasponu od $79 \%$ do $88 \%$, a koeficijent zakazivanja sistema (Sc) u rasponu od 1,13 do 1,27 .

Predviđene performanse sistema i isporuka vode za navodnjavanje prema rasprskivačima pomažu u smanjenju: operativnih troškova, gubitaka vode, i znatno se povećava prinos useva.

Ključne reči: navodnjavanje, rasprskivači, uniformnost, voda, efikasnost

\begin{tabular}{|c|c|}
\hline $\begin{array}{l}\text { Prijavljen: } \\
\text { Submitted: }\end{array}$ & 09.08.2019 \\
\hline $\begin{array}{l}\text { Ispravljen: } \\
\text { Revised: }\end{array}$ & 20.10 .2019 \\
\hline $\begin{array}{l}\text { Prihvaćen: } \\
\text { Accepted: }\end{array}$ & 25.10 .2019 \\
\hline
\end{tabular}

